CLINICAL STUDY

\title{
The analysis of quantitative expression of somatostatin and dopamine receptors in gastro-entero-pancreatic tumours opens new therapeutic strategies
}

\author{
Dermot O'Toole ${ }^{1, *}$, Alexandru Saveanu ${ }^{3,4, *}$, Anne Couvelard ${ }^{2}$, Ginette Gunz ${ }^{3}$, Alain Enjalbert ${ }^{3,4}$, Philippe Jaquet ${ }^{3}$, \\ Philippe Ruszniewski ${ }^{1}$ and Anne Barlier ${ }^{3,4}$ \\ ${ }^{1}$ Service of Gastroentérologie-Pancréatologie, Pôle de maladies de l'appareil Digestif and ${ }^{2}$ Service of Anatomo-pathologie, Hôpital Beaujon, Clichy, France, \\ ${ }^{3}$ Laboratory Interactions Cellulaires Neuroendocriniennes, CNRS-UMR6544, Institut Fédératif Jean-Roche, Faculté de Médecine Nord, Université de la \\ Méditerranée, Marseille, France and ${ }^{4}$ Laboratory of Biochemistry and Molecular Biology, Centre Hospitalo-Universitaire Conception, Marseille, France \\ (Correspondence should be addressed to A Barlier at Laboratory Interactions Cellulaires Neuroendocriniennes, CNRS-UMR6544, Institut Fédératif \\ Jean-Roche, Marseille, France; Email: barliera@jean-roche.univ-mrs.fr)
}

*D O'Toole and A Saveanu contributed equally to this work.

\begin{abstract}
Objective: Somatostatin (sst) are present in the majority of gastro-entero-pancreatic (GEP) tumours. Effects of somatostatin receptor (sst) analogues are partial and of limited duration. Cell lines derived from GEP express dopaminergic receptors $\mathrm{D}_{2}$. New chimeric analogues simultaneously recognising sst $_{2}$ and $\mathrm{sst}_{5}$ or $\mathrm{sst}_{2}$ and $\mathrm{D}_{2}$ have additive effects in inhibition of $\mathrm{GH}$ and prolactin secretion in pituitary adenomas. Our aim was to quantify the expression of sst and $\mathrm{D}_{2}$ mRNA in human GEP tumours. Design and methods: mRNA expression of $\mathrm{sst}_{1}, \mathrm{sst}_{2}, \mathrm{sst}_{3}$ and $\mathrm{sst}_{5}$ as well as $\mathrm{D}_{2}$, was analysed using realtime PCR (TaqMan probe) in a series of 35 patients with GEP tumours (pancreas $(n=19)$ and intestinal $(n=16))$. Levels of expression were compared with a group of 13 somatotroph adenomas.

Results: All GEP tumours express $\mathrm{sst}_{1}, \mathrm{sst}_{2}$ and $\mathrm{D}_{2}$. Expression of $\mathrm{sst}_{3}$ and $\mathrm{sst}_{5}$ was observed in 89 and $76 \%$ of tumours respectively with highly variable levels. sst $_{2}$ mRNA expression was higher in nonfunctional tumours $(P<0.009)$ and sst5 was higher in pancreatic than in intestinal tumours $(P<0.02)$. Whereas sst ${ }_{2}$ levels were similar between GEP and somatotroph tumours, levels of sst ${ }_{5}$ and $\mathrm{D}_{2}$ were higher in the former $\left(394.9 \pm 156.1 \times 10^{-2}\right.$ vs $69.7 \pm 19.5 \times 10^{-2}$ copy/copy $\beta$-Gus $(P<0.0036)$ and $519.6 \pm 121.2 \times 10^{-\overline{2}}$ vs $50.0 \pm 21.6 \times 10^{-2}$ copy/copy $\beta$-Gus $(P<0.0001)$ respectively). In small tumours $(<30 \mathrm{~mm})$, sst $_{2}$ density appeared as a crucial parameter in somatostatin receptor scintigraphy results, whereas in big tumours, a consistent bias in SRS results was introduced by the size. In pancreatic GEP, high-level $\mathrm{sst}_{3}$ expression was found in tumours with more active angiogenesis (higher microvessel density and vascular endothelial growth factor expression $(P<0.03))$.

Conclusions: GEP tumours co-express sst ${ }_{2}$ and $\mathrm{D}_{2}$ in $100 \%$ of cases and $\mathrm{sst}_{5}$ in $89 \%$ thus supporting the testing of bi-specific agonists $\left(\mathrm{sst}_{2} / \mathrm{sst}_{5}\right.$ or $\left.\mathrm{sst}_{2} / \mathrm{D}_{2}\right)$ in these tumours.
\end{abstract}

European Journal of Endocrinology 155 849-857

\section{Introduction}

Somatostatin receptor (sst) subtype status has been characterised using various techniques in gastroentero-pancreatic (GEP) tumours, however, results are heterogeneous and depend on tumour types (1-4). Relatively, few data are available concerning semiquantitative sst expression from studies using densitometry from autoradiography, immunohistochemistry and RT-PCR analysis (3, 5, 6). Differential expression of sst subtypes, but especially $\mathrm{sst}_{2}$, appears important in predicting results of somatostatin receptor scintigraphy (SRS) and therapeutic response to cold somatostatin analogues (7-13). A good correlation has been found to exist between RT-PCR and immunohistochemistry in GEP tumours indicating that the former method may indeed be sufficiently accurate in detecting sst subtypes (5). Real-time PCR adds a quantitative dimension to receptor mRNA detection.

Therapy using standard somatostatin analogues (either daily octreotide or slow-release depot preparations; Octreotide LAR and SR-Lanreotide, sst $_{2}$ agonist) in patients with functional GEP is not universally efficacious and the effects of treatment wane with time (14). Ligands with enhanced receptor binding or those recognising several receptor subtypes may improve clinical outcome and perhaps offer an effective anti-tumoural benefit. BIM23244 , a somatostatin receptor subtypes 2 and 5 
selective analogue was found to have enhanced efficacy in suppressing growth hormone from octreotide-resistant human growth hormone-secreting pituitary adenomas (15). Recently, a multivalent ligand, SOM230, capable of binding to $\mathrm{sst}_{1}, \mathrm{sst}_{2}, \mathrm{sst}_{3}$ and $\mathrm{sst}_{5}$, has been developed with promising results in treatment of patients with acromegaly $(16,17)$ and trials are on-going in patients with symptomatic GEP tumours resistant to standard somatostatin analogue therapy. Better knowledge of sst receptor status in these patients may allow for a tailored approach using such compounds and indeed, quantitative receptor expression may correlate with clinical outcome. A further interesting concept stemmed from combined receptor targeting as demonstrated by the enhanced potency of a chimeric somatostatin-dopamine molecule, BIM23A387, in suppressing growth hormone and prolactin secretion from human pituitary somatotroph adenoma cells in vitro $(18,19)$. Here, the chimeric compound was far more potent than standard somatostatin or dopamine analogues alone (18). Although $\mathrm{D}_{2}$ receptors $\left(\mathrm{D}_{2}\right)$ have been found in the neuroendocrine tumour cell lines, SCAT and BON-1 (20), no data are available in patients with GEP tumours.

The purpose of this study was to quantify sst and $\mathrm{D}_{2}$ receptors mRNA using real-time PCR in a group of patients with GEP tumours originating from the pancreas and small intestine with detailed clinical data available for comparative analysis. The results were compared with a group of patients with somatotroph adenomas.

\section{Subjects and methods}

The study was carried out in 35 patients with GEP tumours (19 men and 16 women), aged $51 \pm 14.7$ years. The present study was approved by the ethics committee of the university and was undertaken after informed consent was obtained from each patient and all participants. The analysis involved only the primary tumour, which had been surgically resected and detailed clinical and pathological characteristics were available in all patients. After surgery, a portion of each tumour tissue was analysed in terms of the quantitative expression of mRNA for the $\mathrm{D}_{2}$ and for $\mathrm{sst}_{1}, \mathrm{sst}_{2}, \mathrm{sst}_{3}$ and sst $_{5}$ receptor subtypes. The primary tumour location included: pancreas $(n=19)$ and intestine $(n=16)$ : ileum, 13; jejunum, 2 and duodenum, 1. The following tumour characteristics were recorded: size (largest perpendicular diameter), functional status (presence or absence of symptoms from hormonal overproduction), SRS results, histological differentiation and WHO status (21). General clinical and tumour characteristics of patients are summarised in Table 1.

Quantitative expression of mRNA for receptors targeted by actual somatostatin and dopamine agonists (sst ${ }_{2}$ and $\mathrm{sst}_{5}$ and $\mathrm{D}_{2}$ ) were compared in patients with GEP tumours to a group of 13 patients with somatotroph adenomas, characterised by immunocytochemistry.

\section{VEGF and microvascular density estimation}

The vascular endothelial growth factor (VEGF) protein was detected by the murine MAB VG1 (22) in pancreatic tumours using a methodology described recently (23) PBS was substituted for primary antibody as the negative control. Positive controls consisted of serum in blood vessels and of islets (detected with strong intensity) in non-tumoural pancreas (adjacent to the tumours). All sections were performed in the same run. The specimens were scanned at a low optical power $(\times 40)$ to study the tissue distribution of staining and at a high optical power $(\times 250)$ to study the cellular staining patterns. The percentage of cells with positive reactivity was scored. A cytoplasmic score was calculated by multiplication of the percentage of cytoplasmic-stained cells by their staining intensity (negative scored as 0 , weak scored as 1 , moderate scored as 2 and strong scored as 3) (23) Microvessel counting was also only available for pancreatic tumours

Table 1 Patient's and tumour characteristics.

\begin{tabular}{lll}
\hline & Pancreatic & Intestinal \\
\hline Total number of cases & 19 & 16 \\
Gender, male/female & $10 / 9$ & $9 / 7$ \\
Age, median years & 49 & 59 \\
Tumour size, mean (range) (mm) & $45.9(9-160)$ & $30(10-60)$ \\
Tumour location & Body/tail: 11 head: 8 & Ileum: 13 Jejunum: 2 Duodenum: 1 \\
Functional status & Glucagon (2), VIP (1), gastrin (1), & $\begin{array}{c}\text { Serotonin-secreting (13), gastrin (1), } \\
\text { non-functional (2) }\end{array}$ \\
Histology classification (WHO) (21) & non-functional (15) & \\
Well-differentiated tumour & 1 & 1 \\
Well-differentiated tumour of 'uncertain' behaviour & 8 & 15 \\
Well-differentiated carcinoma & 9 & 0 \\
Poorly differentiated carcinoma & 1 & Positive: 14 , negative: 1 , not done: 1
\end{tabular}

VIP, vasoactive intestinal peptide. 
and was performed on $\times 200$ fields (area of a $\times 200$ field: $0.442 / \mathrm{mm}^{2}$ ) after CD34 staining. Two areas of high vascularisation were chosen for microvessel counting at a low optical power $(\times 40)$. The final microvessel density (MVD) was the mean value of 3 appraised fields in each area (total area: $2.65 / \mathrm{mm}^{2}$ ). Vessels with a clearly defined lumen or well-defined linear vessel shape were taken into consideration for counting. In addition, the cellular proliferation index, Ki-67 (\%), was calculated using a murine monoclonal MIB-1 antibody (DAKO, Trappes, France) as described previously (23).

\section{Detection of somatostatin receptor and $\mathrm{D} 2$ mRNAs}

Total RNA was extracted from 30 to $60 \mathrm{mg}$ tissue from each tumour using the RNAeasy isolation system (QIAGEN). Tissue sampling was carefully evaluated at microscopy to ensure that sampling was from tumoural tissue and not from adjacent tissues. One microgram of total RNA prepared from tumoural tissues was used for cDNA synthesis with $200 \mathrm{U}$ Superscript II reverse transcriptase (Life Technologies, Inc.) primed with $300 \mathrm{ng}$ random primer (18).

The $5^{\prime}$ exonuclease (TaqMan) assay, which produces a direct proportional readout for the progression of PCR, was used. Amplification of cDNA derived from 50 to $150 \mathrm{ng}$ total RNA was performed in a $25 \mu \mathrm{l}$ reaction volume with $300 \mathrm{nM}$ of each primer, $200 \mathrm{nM}$ probe and $12.5 \mu \mathrm{l}$ MasterMix (PE Applied Biosystems, Paris, France). The synthetic sst ${ }_{1}, \mathrm{sst}_{2}, \mathrm{sst}_{3}, \mathrm{sst}_{5}$ and $\mathrm{D}_{2}$ primers and TaqMan probes used in the PCR were described previously $(18,24)$ and were follows (forward $(\mathrm{F})$, reverse $(\mathrm{R})$ primers and probe $(\mathrm{P}))$ :

D2 F: CAAGACCATGAGCCGTAGGAAG, R: TGTGTGTGATGAAGAAGGGCAG, P: CCCAGCAGAAGGAGAAGAAAGCCACTCA; sst1 F: GCTAGGACACTGACAGCCTTTGA, R: GTAGCCTGAAAGCCTTCCCA, P: CCCAAGAAAGGCGCGCGACAAT; sst2 F: GCCTCCAGGGTCCATTAAGG, R: ATTGAGTGGCTCATCCGCC, P: AGAATAAGATCTCTGGGCTGGCTGGAA; sst3 F: TGGGCCTGCTGGGTAACT, R: GATGTAGACGTTGGTGACTGAAGG, P: CATCTATGTGGTCCTGCGGCACACG; sst5 F: CTGGTGCCAAGGACGCT, R: GCTGCCGGATCCTGTCTG, P: ACGCCACGGAGCCGCGT. Forty cycles of two-step PCRannealing extension were performed on an ABI Prism 7700 sequence detection apparatus (PE Applied Biosystems, Paris, France). The sst and $\mathrm{D}_{2}$ mRNA levels were normalised to the B-Gus mRNA levels obtained in the same reaction. The $B$-Gus primers and probe were purchased from PE Applied Biosystems (18). For each measurement, three independent RT-PCR analyses were performed. To produce standard curves for sst, $\mathrm{D}_{2}$ and ß-Gus mRNA, cDNA constructs were produced for each parameter and verified by sequencing. The results were expressed as copy of sst or $\mathrm{D}_{2}$ /copy of $\mathrm{B}$-Gus.

\section{Statistical analysis}

The results are presented as the mean \pm s.e.m. Statistical significance between two unpaired groups was determined by the Mann-Whitney $U$ test. A $P$ value less than 0.05 was considered significant for all tests.

\section{Results}

\section{sst and $D_{2}$ mRNA expression in GEP tumours}

All GEP tumours had constant but variable expression of $\mathrm{sst}_{1}$, sst $\mathrm{s}_{2}$ and $\mathrm{D}_{2}$ (Fig. 1; Table 2). Somatostatin receptor subtypes $\mathrm{sst}_{3}$ and $\mathrm{sst}_{5}$ were expressed in 76 and $89 \%$ of GEP tumours respectively (Table 2). mRNA level expression of sst5 was higher in pancreatic than in intestinal tumours $(P<0.02)$; mRNA level expression of sst2 was also higher in pancreatic than in intestinal GEP; however, this did not achieve statistical significance (Table 2; Fig. 2).

The level of mRNA sst ${ }_{2}$ expression was significantly higher in patients with non-functional tumours $(n=19)$ compared with functional tumours $(n=16,91.7 \pm$ $37.4 \times 10^{-2}$ vs $39.9 \pm 19.7 \times 10^{-2}$ copy/copy $\beta$-Gus, $P<0.009)$.

\section{Comparison with somatotroph adenomas}

Somatostatin receptor subtypes sst ${ }_{2}, \mathrm{sst}_{5}$ and $\mathrm{D}_{2}$ mRNA levels were compared with a group of 13 somatotroph adenomas (Fig. 3). Levels of $\mathrm{sst}_{5}$ and $\mathrm{D}_{2} \mathrm{mRNA}$ were significantly higher in pituitary adenomas compared with GEP tumours $(P<0.0036$ and $P<0.0001$ respectively), whereas $\mathrm{sst}_{2} \mathrm{mRNA}$ levels were similar. Levels of sst $_{5}$ and $\mathrm{D}_{2}$ mRNA were in the range of those observed in somatotroph adenomas in 43 and $17 \%$ of GEP tumours respectively.

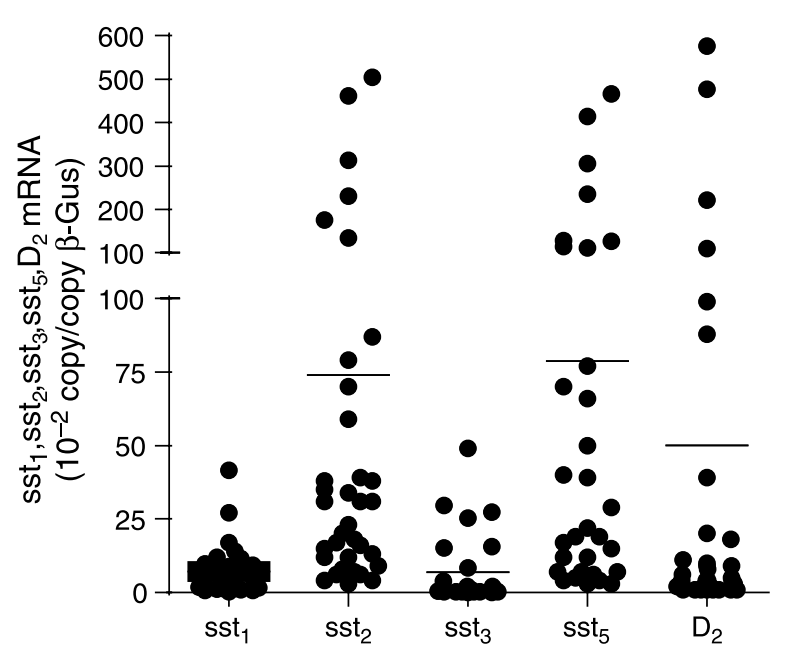

Figure 1 sst $_{1}, s_{2}, s_{2} t_{3}$, sst st $_{5}$ and $D_{2}$ mRNA levels in 35 GEP tumours (19 pancreatic and 16 intestinal). The quantification was performed by real-time PCR. Measurements were reported to the level of $\beta$-Gus. 
Table 2 Expression levels of $s_{1}, s_{1} s_{2}, s_{3}, s_{3} t_{5}$ and $D_{2}$ in GEP tumours and in pituitary adenomas.

\begin{tabular}{|c|c|c|c|c|}
\hline \multirow[b]{3}{*}{ Receptor subtype } & \multicolumn{4}{|c|}{ Mean \pm s.E.M. copy/copy $\beta$-Gus } \\
\hline & \multicolumn{3}{|c|}{ GEP tumours $(n=35)$} & \multirow[b]{2}{*}{ Somatotroph adenomas $(n=13)$} \\
\hline & Pancreatic & Mid gut & GEP & \\
\hline sst $_{1}$ & $6.6 \pm 2.5(100 \%)$ & $7.3 \pm 1.1(100 \%)$ & $7.0 \pm 1.4(100 \%)$ & ND \\
\hline $\mathrm{sst}_{2}$ & $102.4 \pm 33.8(100 \%)$ & $39 \pm 18.7(100 \%)$ & $73.8 \pm 20.7(100 \%)$ & $115.9 \pm 32.0(100 \%)$ \\
\hline $\mathrm{sst}_{3}$ & $11.1 \pm 3.6(84 \%)$ & $1.2 \pm 0.1(63 \%)$ & $6.8 \pm 2.3(76 \%)$ & ND \\
\hline $\mathrm{sst}_{5}$ & $128.5 \pm 39.8(79 \%)$ & $31.8 \pm 9.6(100 \%)$ & $69.7 \pm 19.5(89 \%)$ & $394.9 \pm 156.1(100 \%)$ \\
\hline $\mathrm{D}_{2}$ & $65.9 \pm 37.8(100 \%)$ & $31 \pm 14.7(100 \%)$ & $50.0 \pm 21.6(100 \%)$ & $519.6 \pm 121.2(100 \%)$ \\
\hline
\end{tabular}

The percentages of tumours expressing a subtype receptor are indicated in parenthesis. ND, not done.

\section{sst expression compared with tumour stage and SRS status}

Level of mRNA for $\mathrm{sst}_{2}$ and $\mathrm{sst}_{3}$ was significantly higher in WHO stages 1-2 compared with stage 3 $\left(115 \pm 48 \times 10^{-2}\right.$ vs $60 \pm 22 \times 10^{-2} \quad(P<0.03)$ and $17 \pm 7 \times 10^{-2}$ vs $4 \pm 2.4 \times 10^{-2}(P<0.00673)$ copy/ copy $\beta$-Gus respectively). However, as the majority of intestinal tumours tested were stage 3 , this analysis may be biased by the tumour type. These differences were not apparent when pancreatic tumours were considered alone $\left(n=8,115 \pm 48 \times 10^{-2}\right.$ vs $n=9$, $91 \pm 43 \times 10^{-2}$ copy/copy $\beta$-Gus) thus confirming that these effects may be attributable to tumour type alone. mRNA levels of sst $_{2}$ and sst $_{5}$ were also compared with SRS results (available in 34 patients, Table 1): sst $_{2}$ levels were higher in SRS-positive $(n=27)$ than in SRSnegative $(n=7)$ tumours $\left(87.1 \pm 26.3 \times 10^{-2}\right.$ and $28.4 \pm 10.6 \times 10^{-2}$ copy/copy $\beta$-Gus) without achieving statistical significance. However, when small tumours were considered $(<30 \mathrm{~mm} ; n=16)$ receptor density clearly influenced SRS results: ten SRS-positive patients had a mean sst2 density of $128.3 \pm 48.6 \times 10^{-2}$ vs $31.2 \pm 12.1 \times 10^{-2}$ copy/copy $\beta$-Gus $(P<0.05)$ in six SRS-negative tumours (Fig. 4). Expression of other receptor subtypes had no influence on SRS results,

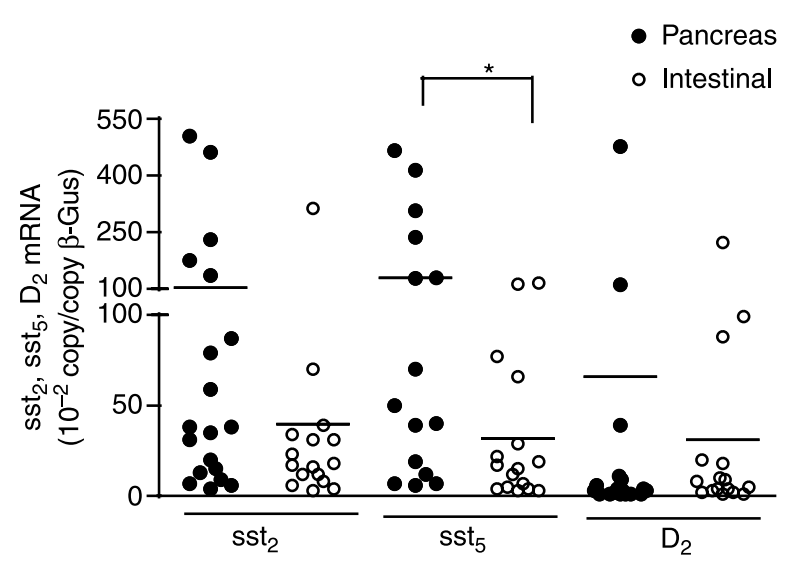

Figure 2 Comparison of mRNA expression levels of $s_{2} t_{2}$, sst $t_{5}$ and $\mathrm{D}_{2}$ mRNA between 19 pancreatic and 16 intestinal tumours. The quantification was performed by real-time PCR. Measurements were reported to the level of $\beta$-Gus. ${ }^{\star} P<0.02$. in fact, mean sst $_{5}$ receptor levels were higher in SRS-negative than in SRS-positive tumours (109.9 \pm $65.9 \times 10^{-2}$ vs $59.4 \pm 19.0 \times 10^{-2}$ copy/copy $\beta$-Gus) however, not statistically significant.

\section{sst and $D_{2}$ expression compared with vascular markers and Ki-67 in pancreatic tumours}

sst and $\mathrm{D}_{2}$ were then analysed with respect to vascular markers, MVD and VEGF, in pancreatic tumours (Table 3). The MVD ranged from 80 to 674 vessels $/ \mathrm{mm}^{2}$ (329 \pm 44). The VEGF score ranged from 0 to $180(58.4 \pm 14.3)$. No correlations were found between MVD and VEGF in relation to $\mathrm{sst}_{1}, \mathrm{sst}_{2}, \mathrm{sst}_{5}$ and $\mathrm{D}_{2}$ receptors. When pancreatic tumours were classified into two groups expressing high-level $\mathrm{sst}_{3}\left(n=7,24 \pm 5 \times 10^{-2}\right.$ copy/ copy $\beta$-Gus) and tumours not expressing or expressing low-level sst ${ }_{3}\left(n=12,0.6 \pm 0.3 \times 10^{-2}\right.$ copy/copy $\beta$-Gus $)$, MVD and VEGF expression were significantly higher in the high-level sst ${ }_{3}$ group $\left(428 \pm 70\right.$ vs $236 \pm 41$ vessels $/ \mathrm{mm}^{2}$ and $94 \pm 25.8$ vs $24.5 \pm 7.4$ respectively, $P<0.03$; Fig. 5), although general low sst ${ }_{3}$ expression.

When tumours were classified into two groups according to the Ki-67 level above 3\% $(n=9,7.2 \pm$ $0.6)$ or below $3 \%(n=8,2.6 \pm 0.3)$, sst5 levels were found to be higher in first group compared with the second group $\left(25 \pm 11.8 \times 10^{-2}\right.$ vs $206 \pm 62 \times 10^{-2}$ copy/copy $\beta$-Gus, $P<0.005$; Fig. 6).

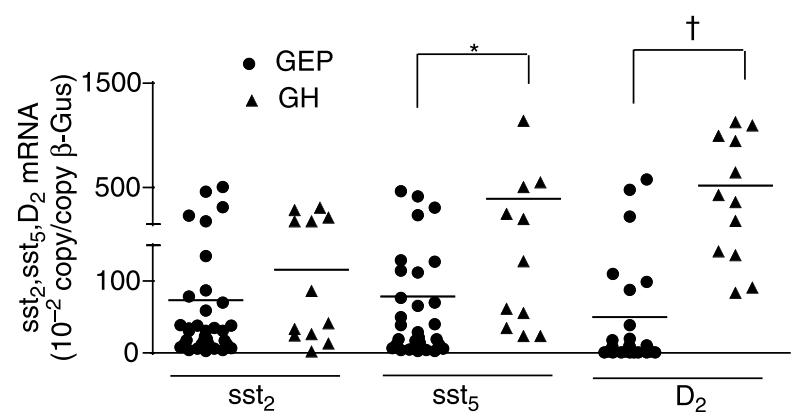

Figure 3 Comparison of mRNA expression level of $s_{2} t_{2}, s s t_{5}$ and $D_{2}$ mRNA between 35 GEP tumours and 13 somatotroph adenomas $(\mathrm{GH})$. Quantification was performed by real-time PCR. Measurements were reported to the level of $\beta$-Gus. ${ }^{\star} P<0.0036$; ${ }^{\dagger} P<0.0001$. 


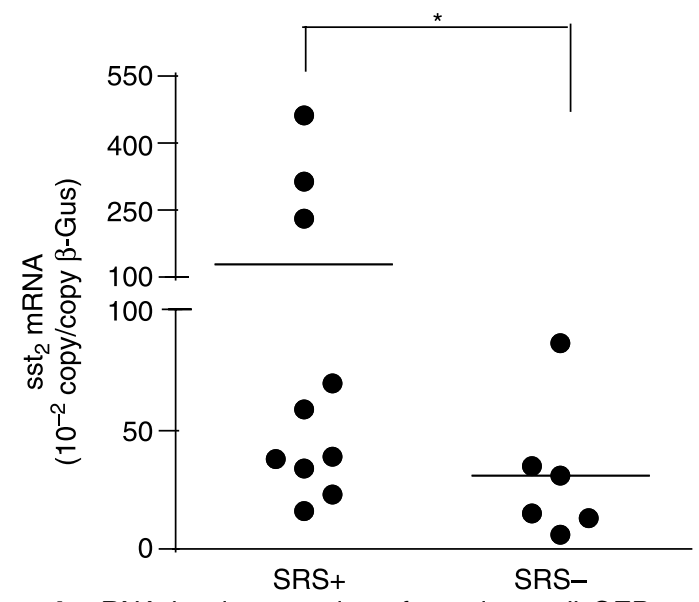

Figure 4 mRNA level expression of $s t_{2}$ in small GEP tumours $(<30 \mathrm{~mm})$ according to the SRS-positive $(n=10)$ or SRS-negative patients $(n=6)$. The quantification was performed by real-time PCR. Measurements were reported to the level of $\beta$-Gus. ${ }^{\star} P<0.05$.

\section{Discussion}

Somatostatin analogues are widely used in the treatment of GEP tumours and SRS is a useful tool in diagnosis. The general use of SRIF agonists is justified by the presence in these tumours of SRIF receptors detected by qualitative mRNA and protein methods. For the first time, using real-time PCR, we systematically quantified not only sst subtypes but also $\mathrm{D}_{2}$ mRNA, in a large series of human GEP tumours. All GEP tumours expressed sst $_{1}$, sst $_{2}$ and $\mathrm{D}_{2}$ while only 76 and $89 \%$ of tumours expressed $\mathrm{sst}_{3}$ and $\mathrm{sst}_{5}$ respectively. These results are close to those of Papotti et al using semi-quantitative PCR and immunohistochemistry with a good correlation between these two techniques (5). In our series, the expression levels were higher for $\mathrm{sst}_{2}$ and $\mathrm{sst}_{5}$ and markedly lower for $\mathrm{sst}_{1}$ and $\mathrm{sst}_{3}$. Note that nonfunctioning GEP tumours had a significantly higher level of $\mathrm{sst}_{2}$ than functional ones $(P<0.009)$; however, the significance of this remains to be determined. Similar results concerning $\mathrm{sst}_{2}$ and $\mathrm{sst}_{5}$ were also previously observed in 38 patients with GEP (mostly pancreatic) using semi-quantitative PCR, although sst ${ }_{1}$ and $\mathrm{sst}_{3}$ were less frequently observed (66 and $50 \%$ respectively) (3). Compared with a group of pituitary tumours, the level of sst $_{5}$ mRNA expression was less while sst $_{2}$ expression levels were almost similar (Table 2). In a group of 27 ileal carcinoids, Reubi and Wasser (6) found $\mathrm{sst}_{2}$ to have the highest density (5.4 d.p.m./mg tissue) followed by $\mathrm{sst}_{1}, \mathrm{sst}_{5}, \mathrm{sst}_{3}$ and sst $_{4}(3.4,2.4,1.6$ and 1.5 d.p.m./mg tissue respectively). However, comparison of techniques using ligand binding and mRNA detection is difficult. Indeed, techniques focused on protein detection may reflect more accurate levels of sst receptors, whereas PCR may have overestimated quantities expressed. Moreover, the use of PCR does not allow for analysis of the percentage of cells expressing different receptor subtypes which requires in situ hybridisation or immunohistochemistry; indeed, the heterogeneity of sst expression has been previously described (5).

Although the dopamine receptors and the transmembrane dopamine transporter are known to play an important role in gastrointestinal physiology (25), they

Table 3 Expression levels of $\mathrm{sst}_{1}, \mathrm{sst}_{2}, \mathrm{sst}_{3}, \mathrm{sst}_{5}$ and $\mathrm{D}_{2}$ receptors according to the microvascular density (MVD) as measured by microscopy using CD34 staining (vessels $/ \mathrm{mm}^{2}$ ), vascular endothelial growth factor (VEGF, measured as a score by multiplication of the percentage of stained cells by their staining intensity 0 ) by immunohistochemistry and cellular proliferation index (Ki-67) in 19 pancreatic tumours.

\begin{tabular}{|c|c|c|c|c|c|c|c|c|}
\hline \multirow[b]{2}{*}{ Tumour } & \multirow[b]{2}{*}{ VEGF score } & \multirow[b]{2}{*}{ MVD (vessels/mm²) } & \multirow[b]{2}{*}{ Ki-67 (\%) } & \multicolumn{5}{|c|}{$10^{-2}$ Copy/copy/ $\beta$-Gus } \\
\hline & & & & sst $_{1}$ & $\mathrm{sst}_{2}$ & $\mathrm{sst}_{3}$ & $\mathrm{sst}_{5}$ & $\mathrm{D}_{2}$ \\
\hline C1 & 180 & 496 & 7 & 4.3 & 175.0 & 49.0 & 7.0 & 1.0 \\
\hline C2 & 10 & 95 & 3 & 0.9 & 7.0 & 0.3 & 236.0 & 4.0 \\
\hline C3 & 180 & 400 & 9 & 1.2 & 9.0 & 0.3 & 7.0 & 3.0 \\
\hline $\mathrm{C} 4$ & 50 & 209 & 2 & 0.7 & 6.0 & 0.3 & 414.0 & 1.0 \\
\hline C5 & 20 & 173 & 3 & 27.1 & 13.0 & 0.3 & 306.0 & 39.0 \\
\hline C6 & 50 & 674 & 5 & 1.3 & 31.0 & 27.3 & 0.0 & 1.0 \\
\hline C7 & 150 & 417 & 3 & 3.5 & 38.0 & 25.2 & 12.0 & 4.0 \\
\hline C8 & 160 & 100 & 8 & 3.4 & 79.0 & 15.2 & 0.0 & 1.0 \\
\hline C9 & 0 & 102 & 3 & 0.2 & 20.0 & 3.9 & 70.0 & 6.0 \\
\hline C10 & 40 & 276 & 4 & 0.6 & 135.0 & 0.0 & 127.0 & 110.0 \\
\hline C11 & 60 & 652 & 7 & 1.6 & 15.0 & 1.0 & 40.0 & 2.0 \\
\hline C12 & 0 & 337 & 5 & 41.6 & 35.0 & 0.1 & 0.0 & 576.0 \\
\hline $\mathrm{C} 13$ & 30 & 464 & 4 & 7.4 & 461.0 & 0.0 & 466.0 & 9.0 \\
\hline C14 & 60 & 563 & 1 & 4.5 & 38.0 & 15.5 & 19.0 & 3.0 \\
\hline C15 & 60 & 442 & 6 & 7.3 & 230.0 & 8.4 & 129.0 & 1.0 \\
\hline C16 & 0 & 307 & 9 & 2.7 & 59.0 & 29.7 & 0.0 & 1.0 \\
\hline C17 & 0 & 80 & 10 & 9.2 & 504.0 & 0.3 & 39.0 & 477.0 \\
\hline C18 & 0 & 357 & 4 & 1.9 & 87.0 & 0.5 & 6.0 & 11.0 \\
\hline C19 & 60 & 112 & 9 & ND & 4.0 & 0.3 & 50.0 & 3.0 \\
\hline Mean \pm s.D. & $58.4 \pm 14.3$ & $329 \pm 44$ & $5.3(1-10)$ & $6.6 \pm 2.5$ & $102 \pm 33$ & $11 \pm 3.6$ & $128 \pm 40$ & $65 \pm 37$ \\
\hline
\end{tabular}




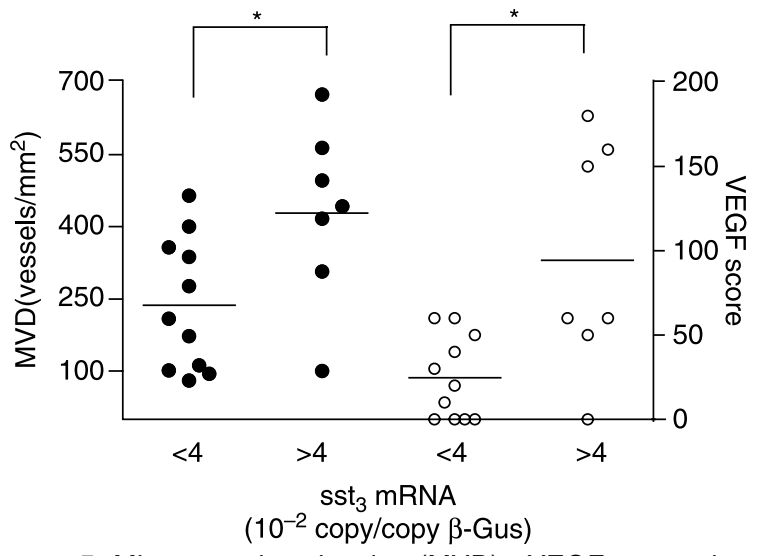

Figure 5 Microvascular density (MVD), VEGF score in 19 pancreatic tumours expressing a high level $(>4)$ or a low level $(<4)$ of sst3 mRNA. MVD were evaluated by microscopy, VEGF score by immunocytochemisty (measured as a score by multiplication of the percentage of stained cells by their staining intensity) and $\mathrm{sst}_{3}$ by real-time PCR. ${ }^{*} P<0.03$.

have not been investigated in neuroendocrine gastrointestinal tumours. Interestingly, Lemmer et al. have showed the presence of $\mathrm{D}_{2}$ in two cell lines, STC1 murine neuroendocrine gut tumours and $\mathrm{BON}$ human pancreatic neuroendocrine tumours (20). Here, we showed for the first time the presence of $\mathrm{D}_{2} \mathrm{mRNA}$ in all human GEP tumours. Moreover, the quantitative analysis showed that $\mathrm{D}_{2}$ expression level was in the range of those observed in somatotroph adenomas in $17 \%$ of GEP tumours. The identification of $\mathrm{D}_{2}$ in all GEP tumours of both intestinal and pancreatic origin opens the possibility of examining new chimeric analogues which simultaneously recognise sst $_{2}$ and $D_{2}$, such as BIM-23A387 or BIM-23A370, which have been shown to enhance the suppression of growth hormone and

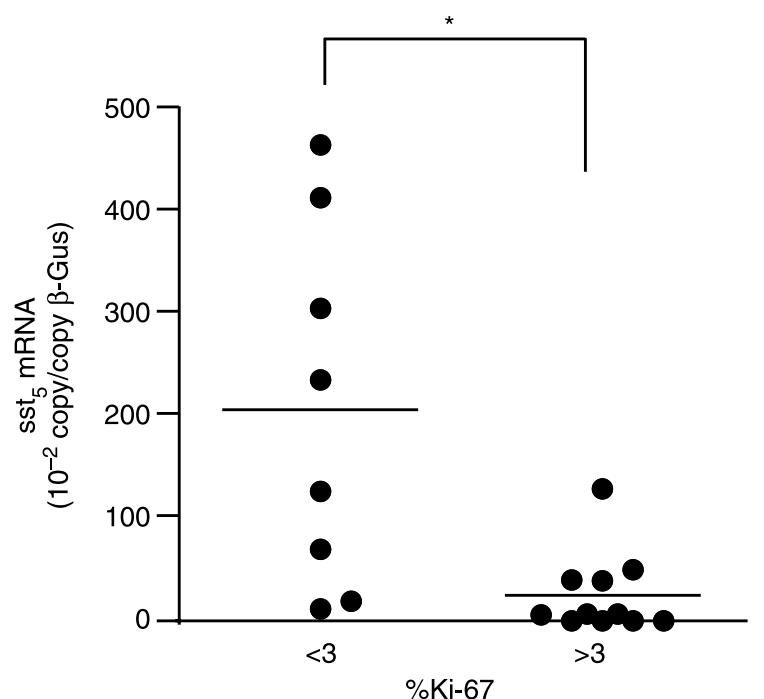

Figure 6 Nineteen pancreatic tumours were classified into two groups according to the level of \% Ki-67 (above or below $3 \%$ ). sst $_{5}$ were evaluated by real-time PCR. ${ }^{*} P<0.005$. prolactin in pituitary adenomas compared with $\mathrm{sst}_{2}$ and $\mathrm{D}_{2}$ analogues used alone $(18,26)$. A direct antiproliferative effect of the somatostatin/dopamine chimeras, BIM-23A387 and BIM-23A370, was found in the lung carcinoma cell line (Calu-6) possible via sst/ $\mathrm{D}_{2}$ dimerisation (27). In addition, other analogues capable of recognising both $\mathrm{sst}_{2}$ and $\mathrm{sst}_{5}$ (BIM-23 244) or the multivalent agonist SOM230 (recognising sst ${ }_{1}, \mathrm{sst}_{2}, \mathrm{sst}_{3}$ and $\mathrm{sst}_{5}$ ) offer the possibility of increasing therapeutic efficacy by acting via more than one receptor. Although $\mathrm{D}_{2}$ was found in all tumours, low levels were expressed in about $80 \%$ inferring that $D_{2}$ receptor targeting may only be relevant to subset of patients with GEP tumours. Moreover, cellular distribution of sst and $\mathrm{D}_{2}$ receptors should also be an important parameter involved in the efficacy of such treatment. Examining the potential effect on tumour secretion or even proliferation in GEP tumours will require functional studies.

Somatostatin receptor scintigraphy is performed not only for tumoural localisation but also for predicting the efficacy of somatostatin agonist or modified radiopharmaceutical analogues (28-31). However, in some case, SRS results were not correlated with results of treatments (32-34). Actual SRS using ${ }^{111}$ pentetreotide recognises mostly $s_{2} t_{2}$ subtype. Pentetreotide had tenfold higher affinity for $\mathrm{sst}_{2}$ than for $\mathrm{sst}_{5} \mathrm{or}_{\mathrm{sst}} \mathrm{s}_{3}(6)$. Globally, SRS is positive in approximately $80 \%$ of all patients with GEP tumours (35). Previously, semiquantitative RT-PCR revealed most prominently $\mathrm{sst}_{2}$ expression in scintigraphic positive tumours (36). Using $\mathrm{sst}_{2}$ knockout mice, Hofland and collaborators confirmed the crucial role of $\mathrm{sst}_{2}$ in determining the uptake of $\left[{ }^{111}\right.$ In DTPA-D-Phe]octreotide (28). In the present study, we confirm $\mathrm{sst}_{2}$ as the most important receptor subtype in case of positive SRS uptake as the levels of $\mathrm{sst}_{2}$ in $27 \mathrm{SRS}$-positive tumours was markedly higher as compared with seven SRS-negative tumours. Levels of other sst did not differ between SRS-positive and SRS-negative tumours thus confirming that other sst have less influence on SRS outcome (36). Jais et al previously observed no difference in sst receptor distribution and SRS results although again numbers were small (17 positive SRS vs 4 negative) (3). In the present study, when only small tumours $(<30 \mathrm{~mm})$ were examined, sst $_{2}$ mRNA level expression was significantly higher in SRS-positive tumours than in SRS-negative ones (Fig. 4), thus confirming the crucial role of $\mathrm{sst}_{2}$ receptor alone on scintigraphic results for small tumours. Moreover, compared with SRS-negative tumours, SRS-positive tumours were larger $(44 \pm 7$ vs $21 \pm 2.7 \mathrm{~mm}, P<0.01$, data not shown) confirming the role of tumour size itself on scintigraphic results for the large tumours. Among all SRS-positive tumours, $\mathbf{s s t}_{2}$ mRNA levels were significantly higher in the group of small versus big tumours $\left(128 \pm 48 \times 10^{-2}\right.$ vs $73 \pm$ $48 \times 10^{-2}$ copy/ $\beta$-Gus copy, $P<0.05$, data not shown) confirming the bias introduced by the size in SRS results. 
sst level expression and in particular sst 2 may predict clinical response to somatostatin receptor analogues and could thus help in tailoring targeted therapy as shown in somatotroph adenomas $(37,24)$. As in patients with breast cancer where oestrogen receptor status and levels help in predicting therapeutic responses, quantitative receptor measurements may help in determining responses to cold and radiolabelled somatostatin (or somatostatin-dopamine) analogues to be used in treatment according to analogues binding characteristics $(38,39)$.

As well as being involved in regulation of hormonal release, sst are known to have direct and indirect effects on angiogenesis and cellular proliferation (review: (40)). Interestingly, sst3 was higher in pancreatic than in intestinal tumours (Table 2). Thus, when pancreatic tumours were separated into high and low sst $_{3}$ level groups, a positive correlation with both microvessel density and VEGF score $(P<0.03)$ was observed (Fig. 5). MVD and VEGF expression have been found to be increased in benign pancreatic tumours and their expression decreases as tumours dedifferentiate (23). $\mathrm{sst}_{3}$ has previously been found to be the predominant somatostatin receptor subtype in endothelial cells (41). sst $_{3}$ may be expressed also in the microvessels of the tumours of our series. Nevertheless, the observation of co-expression of angiogenic factors with $\mathrm{sst}_{3}$ is important as underlined by the recent observation that somatostatin inhibition of tumour angiogenesis in a Kaposi's sarcoma cell xenograft model occurred via sst ${ }_{3}$ mediated inhibition of both nitric oxide synthetase and MAPK activities (42). In endothelial cells-expressing $\mathrm{sst}_{3}$, addition of the $\mathrm{sst}_{3}$ antagonist, BN81658, significantly reversed the anti-angiogenic effects of somatostatin (42). VEGF and somatostatin were also recently found to be co-expressed in the same tissue compartments in ovarian cancer suggesting a major role for somatostatin in angiogenesis (43).

Finally, low sst $_{5}$ mRNA expression was present in pancreatic tumours with high Ki-67 level. Overall, few data are available comparing sst receptors with cellular markers of proliferation. Interestingly, our results were contradictory to recent data in a series of 16 insulinomas, where $s t_{5}$ was positively correlated with aggressive tumour behaviours, such as large tumour size, tumours of uncertain behaviour and presence of nuclear atypia (44). In brain tumours (astrocytomas and meninginomas), no relation existed between Ki-67 and sst subtypes in two series $(45,46)$. In contrast, in breast cancer, sst $_{2}$ mRNA expression was significantly higher in low-proliferating (as measured using Ki-67) breast cancers (47). Note that in an endothelial cell line model (HUVEC) sst other than sst2 and sst3 appears important in controlling proliferation as demonstrated by the ability of the multivalent ligand SOM230, but not octreotide, to inhibit proliferation and this did not appear to be mediated via sst 3 as only $\mathrm{sst}_{1}, \mathrm{sst}_{2}$ and $\mathrm{sst}_{5}$ were detected using RT-PCR and western blotting (48).
SOM230 or other specific $\mathrm{sst}_{2}-\mathrm{sst}_{5}$ or $\mathrm{sst}_{2}-\mathrm{D}_{2}$ agonists may thus represent suitable candidates as potential anti-angiogenic and anti-proliferating drugs.

In conclusion, GEP tumours were found to co-express sst $_{2}$ and $\mathrm{D}_{2}$ in all cases and $\mathrm{sst}_{5}$ in $89 \%$. SRS results were strongly correlated to the $\mathrm{sst}_{2} \mathrm{mRNA}$ expression level in small tumours $(<30 \mathrm{~mm})$, but were consistently distorted by the size in large tumours explaining some discordance between SRS and somatostatin treatment results. While mean level of receptor expression for $\mathrm{sst}_{5}$ and $\mathrm{D}_{2}$ is lower in GEP than in pituitary adenomas, comparative levels are observed in almost a half and a fifth of tumours respectively. These results argue for testing of bi-specific agonists $\left(\mathrm{sst}_{2} / \mathrm{sst}_{5}\right.$ or $\left.\mathrm{sst}_{2} / \mathrm{D}_{2}\right)$ in the treatment of GEP tumours not only for inhibiting secretion but also angiogenesis and cell proliferation.

\section{Funding}

The present study was supported in part by Biomeasure, Inc. (Milford, MA, USA), by Centre national de la Recherche Scientifique, by the Association pour le Développement des Recherches Médicales au Centre Hospitalier Régional de Marseille (ADEREM) and by an educational grant from Beaufour Ipsen Pharma.

\section{References}

1 Kubota A, Yamada Y, Kagimoto S, Shimatsu A, Imamura M, Tsuda K, Imura H, Seino S \& Seino Y. Identification of somatostatin receptor subtypes and an implication for the efficacy of somatostatin analogue SMS 201-995 in treatment of human endocrine tumors. Journal of Clinical Investigation 199493 1321-1325.

2 Reubi JC, Waser B, Schaer JC \& Laissue JA. Somatostatin receptor sst1-sst5 expression in normal and neoplastic human tissues using receptor autoradiography with subtype-selective ligands. European Journal of Nuclear Medicine 200128 836-846.

3 Jais P, Terris B, Ruszniewski P, Leromancer M, Reyl-Desmars F, Vissuzaine C, Cadiot G, Mignon M \& Lewin MJ. Somatostatin receptor subtype gene expression in human endocrine gastroentero-pancreatic tumours. European Journal of Clinical Investigation 199727 639-644.

4 Volante M, Bozzalla-Cassione F \& Papotti M. Somatostatin receptors and their interest in diagnostic pathology. Endocrine Pathology 200415 275-291.

5 Papotti M, Bongiovanni M, Volante M, Allia E, Landolfi S, Helboe L, Schindler M, Cole SL \& Bussolati G. Expression of somatostatin receptor types 1-5 in 81 cases of gastrointestinal and pancreatic endocrine tumors. A correlative immunohistochemical and reverse-transcriptase polymerase chain reaction analysis. Virchows Archiv $2002 \mathbf{4 4 0} 461-475$.

6 Reubi JC \& Waser B. Concomitant expression of several peptide receptors in neuroendocrine tumours: molecular basis for in vivo multireceptor tumour targeting. European Journal of Nuclear Medicine and Molecular Imaging 200330 781-793.

7 Lamberts SW, Hofland LJ, Van Koetsveld PM, Reubi JC, Bruining HA, Bakker WH \& Krenning EP. Parallel in vivo and in vitro detection of functional somatostatin receptors in human endocrine pancreatic tumors: consequences with regard to diagnosis, localization, and therapy. Journal of Clinical Endocrinology and Metabolism 199071 566-574. 
8 Kvols LK, Reubi JC, Horisberger U, Moertel CG, Rubin J \& Charboneau JW. The presence of somatostatin receptors in malignant neuroendocrine tumor tissue predicts responsiveness to octreotide. Yale Journal of Biology and Medicine 199265 505-518 (Discussion 531-506).

9 Janson ET, Westlin JE, Eriksson B, Ahlstrom H, Nilsson S \& Oberg K. [111In-DTPA-D-Phe1] octreotide scintigraphy in patients with carcinoid tumours: the predictive value for somatostatin analogue treatment. European Journal of Endocrinology 1994131 577-581.

10 Janson ET, Stridsberg M, Gobl A, Westlin JE \& Oberg K. Determination of somatostatin receptor subtype 2 in carcinoid tumors by immunohistochemical investigation with somatostatin receptor subtype 2 antibodies. Cancer Research 199858 2375-2378.

11 Hofland LJ, Liu Q, Van Koetsveld PM, Zuijderwijk J, Van Der Ham F, De Krijger RR, Schonbrunn A \& Lamberts SW. Immunohistochemical detection of somatostatin receptor subtypes sst1 and sst2A in human somatostatin receptor positive tumors. Journal of Clinical Endocrinology and Metabolism 199984 775-780.

12 Reubi JC, Schar JC, Waser B, Wenger S, Heppeler A, Schmitt JS \& Macke HR. Affinity profiles for human somatostatin receptor subtypes SST1-SST5 of somatostatin radiotracers selected for scintigraphic and radiotherapeutic use. European Journal of Nuclear Medicine 200027 273-282.

13 Papotti M, Croce S, Bello M, Bongiovanni M, Allia E, Schindler M \& Bussolati G. Expression of somatostatin receptor types 2, 3 and 5 in biopsies and surgical specimens of human lung tumours. Correlation with preoperative octreotide scintigraphy. Virchows Archiv 2001439 787-797.

14 Hofland LJ \& Lamberts SW. The pathophysiological consequences of somatostatin receptor internalization and resistance. Endocrine Reviews $20032428-47$.

15 Saveanu A, Gunz G, Dufour H, Caron P, Fina F, Ouafik L, Culler MD, Moreau JP, Enjalbert A \& Jaquet P. Bim-23244, a somatostatin receptor subtype 2-and 5-selective analog with enhanced efficacy in suppressing growth hormone (GH) from octreotide-resistant human GH-secreting adenomas. Journal of Clinical Endocrinology and Metabolism 2001 86 140-145.

16 Van Der Hoek J, Van Der Lelija J, Feelders RA, De Herder WW, Uitterlinden P, Poon KW, Boerlin V, Lewis I, Krahnke T, Hofland LJ \& Lamberts SW. The somatostatin analogue SOM230, compared with octreotide, induces differential effects in several metabolic pathways in acromegalic patients. Clinical Endocrinology (Oxf) 200563 176-184.

17 Van Der Hoek J, De Herder WW, Feelders RA, Van Der Lely AJ, Uitterlinden P, Boerlin V, Bruns C, Poon KW, Lewis I, Weckbecker G, Krahnke T, Hofland LJ \& Lamberts SW. A single-dose comparison of the acute effects between the new somatostatin analog SOM230 and octreotide in acromegalic patients. Journal of Clinical Endocrinology and Metabolism $200489638-645$.

18 Saveanu A, Lavaque E, Gunz G, Barlier A, Kim S, Taylor JE, Culler MD, Enjalbert A \& Jaquet P. Demonstration of enhanced potency of a chimeric somatostatin-dopamine molecule, BIM23A387, in suppressing growth hormone and prolactin secretion from human pituitary somatotroph adenoma cells. Journal of Clinical Endocrinology and Metabolism 200287 5545-5552.

19 Jaquet P, Saveanu A \& Barlier A. New SRIF analogs in the control of human pituitary adenomas: perspectives. Journal of Endocrinological Investigation $2005 \mathbf{2 8} 14-18$.

20 Lemmer K, Ahnert-Hilger G, Hopfner M, Hoegerle S, Faiss S, Grabowski P, Jockers-Scherubl M, Riecken EO, Zeitz M \& Scherubl H. Expression of dopamine receptors and transporter in neuroendocrine gastrointestinal tumor cells. Life Science 200271 667-678.

21 Solcia E \& Klöppel G. Histological typing of endocrine tumours. In Histological Typing of Endocrine Tumours (International Classification of Tumours), EdsEdE Solcia, G Klöppel \& Lh Sobin, Berlin: Springer, 2000.

22 Turley H, Scott PA, Watts VM, Bicknell R, Harris aL \& Gatter KC. Expression of VEGF in routinely fixed material using a new monoclonal antibody VG1. Journal of Pathology $1998 \mathbf{1 8 6} 313-318$.
23 Couvelard A, O'toole D, Turley H, Leek R, Sauvanet A, Degott C, Ruszniewski P, Belghiti J, Harris AL, Gatter K \& Pezzella F. Microvascular density and hypoxia-inducible factor pathway in pancreatic endocrine tumours: negative correlation of microvascular density and VEGF expression with tumour progression. British Journal of Cancer 200592 94-101.

24 Jaquet P, Saveanu A, Gunz G, Fina F, Zamora AJ, Grino M, Culler MD, Moreau JP, Enjalbert A \& Ouafik LH. Human somatostatin receptor subtypes in acromegaly: distinct patterns of messenger ribonucleic acid expression and hormone suppression identify different tumoral phenotypes. Journal of Clinical Endocrinology and Metabolism 200085 781-792.

25 Mezey E, Eisenhofer G, Hansson S, Harta G, Hoffman BJ, Gallatz K, Palkovits M \& Hunyady B. Non-neuronal dopamine in the gastrointestinal system. Clinical and Experimental Pharmacology $\mathcal{E}$ Physiology. Supplement 199926 S14-S22.

26 Jaquet P, Gunz G, Saveanu A, Dufour H, Taylor J, Dong J, Kim S, Moreau JP, Enjalbert A \& Culler MD. Efficacy of chimeric molecules directed towards multiple somatostatin and dopamine receptors on inhibition of $\mathrm{GH}$ and prolactin secretion from $\mathrm{GH}$-secreting pituitary adenomas classified as partially responsive to somatostatin analog therapy. European Journal of Endocrinology 2005153 135-141.

27 Ferone D, Arvigo M, Semino C, Jaquet P, Saveanu A, Taylor JE, Moreau JP, Culler MD, Albertelli M, Minuto F \& Barreca A. Somatostatin and dopamine receptor expression in lung carcinoma cells and effects of chimeric somatostatin-dopamine molecules on cell proliferation. American Journal of Physiology, Endocrinology and Metabolism 2005289 E1044-E1050.

28 Hofland LJ, Lamberts SW, Van Hagen PM, Reubi JC, Schaeffer J, Waaijers M, Van Koetsveld PM, Srinivasan A, Krenning EP \& Breeman WA. Crucial role for somatostatin receptor subtype 2 in determining the uptake of [111In-DTPA-D-Phe1]octreotide in somatostatin receptor-positive organs. Journal of Nuclear Medicine $2003441315-1321$.

29 Kulaksiz H, Eissele R, Rossler D, Schulz S, Hollt V, Cetin Y \& Arnold R. Identification of somatostatin receptor subtypes 1, 2A, 3 , and 5 in neuroendocrine tumours with subtype specific antibodies. Gut $2002 \mathbf{5 0} 52-60$.

30 Krenning EP, Kwekkeboom DJ, Bakker WH, Breeman WA, Kooij PP, Oei HY, Van Hagen M, Postema PT, De Jong M, Reubi JC, Visser TJ, Reijs AEM, Hofland LJ, Koper JW \& Lamberts SWJ. Somatostatin receptor scintigraphy with [111In-DTPA-D-Phe1]-and [123I-Tyr3]octreotide: the Rotterdam experience with more than 1000 patients. European Journal of Nuclear Medicine 199320 716-731.

31 Kwekkeboom DJ, Teunissen JJ, Bakker WH, Kooij PP, De Herder WW, Feelders RA, Van Eijck CH, Esser JP, Kam BL \& Krenning EP. Radiolabeled somatostatin analog [177Lu-DOTA0,Tyr3] octreotate in patients with endocrine gastroenteropancreatic tumors. Journal of Clinical Oncology 200523 2754-2762.

32 Plockinger U, Reichel M, Fett U, Saeger W \& Quabbe HJ. Preoperative octreotide treatment of growth hormone-secreting and clinically nonfunctioning pituitary macroadenomas: effect on tumor volume and lack of correlation with immunohistochemistry and somatostatin receptor scintigraphy. Journal of Clinical Endocrinology and Metabolism 1994 79 1416-1423.

33 Nilsson O, Kolby L, Wangberg B, Wigander A, Billig H, WilliamOlsson L, Fjalling M, Forssell-Aronsson E \& Ahlman H. Comparative studies on the expression of somatostatin receptor subtypes, outcome of octreotide scintigraphy and response to octreotide treatment in patients with carcinoid tumours. British Journal of Cancer 199877 632-637.

34 Ricci S, Antonuzzo A, Galli L, Ferdeghini M, Bodei L, Orlandini C \& Conte PF. Octreotide acetate long-acting release in patients with metastatic neuroendocrine tumors pretreated with lanreotide. Annals of Oncology 200011 1127-1130.

35 Lebtahi R, Cadiot G, Sarda L, Daou D, Faraggi M, Petegnief Y, Mignon M \& Le Guludec D. Clinical impact of somatostatin receptor scintigraphy in the management of patients with neuroendocrine gastroenteropancreatic tumors. Journal of Nuclear Medicine 199738 853-858. 
36 John M, Meyerhof W, Richter D, Waser B, Schaer JC, Scherubl H, Boese-Landgraf J, Neuhaus P, Ziske C, Molling K, Riecken EO, Reubi JC \& Wiedenmann B. Positive somatostatin receptor scintigraphy correlates with the presence of somatostatin receptor subtype 2. Gut 199638 33-39.

37 Barlier A, Pellegrini-Bouiller I, Gunz G, Zamora AJ, Jaquet P \& Enjalbert A. Impact of gsp oncogene on the expression of genes coding for Gsalpha, Pit-1, Gi2alpha, and somatostatin receptor 2 in human somatotroph adenomas: involvement in octreotide sensitivity. Journal of Clinical Endocrinology and Metabolism 1999 $842759-2765$.

38 Leers MP, Hoop JG, Van Beers M, Van Rodijnen N, Pannebakker M \& Nap M. Determination of threshold values for determining the size of the fraction of steroid hormone receptor-positive tumor cells in paraffin-embedded breast carcinomas. Cytometry. Part B, Clinical Cytometry 200564 43-52.

39 Ogawa Y, Moriya T, Kato Y, Oguma M, Ikeda K, Takashima T, Nakata B, Ishikawa T \& Hirakawa K. Immunohistochemical assessment for estrogen receptor and progesterone receptor status in breast cancer: analysis for a cut-off point as the predictor for endocrine therapy. Breast Cancer 200411 267-275.

40 Olias G, Viollet C, Kusserow H, Epelbaum J \& Meyerhof W. Regulation and function of somatostatin receptors. Journal of Neurochemistry 200489 1057-1091.

41 Albini A, Florio T, Giunciuglio D, Masiello L, Carlone S, Corsaro A, Thellung S, Cai T, Noonan DM \& Schettini G. Somatostatin controls Kaposi's sarcoma tumor growth through inhibition of angiogenesis. FASEB Journal 199913 647-655.

42 Florio T, Morini M, Villa V, Arena S, Corsaro A, Thellung S, Culler MD, Pfeffer U, Noonan DM, Schettini G \& Albini A. Somatostatin inhibits tumor angiogenesis and growth via somatostatin receptor-3-mediated regulation of endothelial nitric oxide synthase and mitogen-activated protein kinase activities. Endocrinology 2003144 1574-1584.
43 Hall GH, Turnbull LW, Bedford K, Richmond I, Helboe L \& Atkin SL. Neuropilin-1 and VEGF correlate with somatostatin expression and microvessel density in ovarian tumours. International Journal of Oncology 200527 1283-1288.

44 De Sa SV, Correa-Giannella ML, Machado MC, De Souza JJ, Pereira MA, Patzina RA, Siqueira SA, Machado MC \& GiannellaNeto D. Somatostatin receptor subtype 5 (SSTR5) mRNA expression is related to histopathological features of cell proliferation in insulinomas. Endocrine Related Cancer 200613 69-78.

45 Arena S, Barbieri F, Thellung S, Pirani P, Corsaro A, Villa V, Dadati P, Dorcaratto A, Lapertosa G, Ravetti JL, Spaziante R, Schettini G \& Florio T. Expression of somatostatin receptor mRNA in human meningiomas and their implication in in vitro antiproliferative activity. Journal of Neuro Oncology 200466 $155-166$.

46 Mawrin C, Schulz S, Pauli SU, Treuheit T, Diete S, Dietzmann K, Firsching R, Schulz S \& Hollt V. Differential expression of sst1, sst $2 \mathrm{~A}$, and sst 3 somatostatin receptor proteins in low-grade and high-grade astrocytomas. Journal of Neuropathology and Experimental Neurology 200463 13-19.

47 Orlando C, Raggi CC, Bianchi S, Distante V, Simi L, Vezzosi V, Gelmini S, Pinzani P, Smith MC, Buonamano A, Lazzeri E, Pazzagli M, Cataliotti L, Maggi M \& Serio M. Measurement of somatostatin receptor subtype 2 mRNA in breast cancer and corresponding normal tissue. Endocrine Related Cancer 200411 323-332.

48 Adams RL, Adams IP, Lindow SW \& Atkin SL. Inhibition of endothelial proliferation by the somatostatin analogue SOM230. Clinical Endocrinology (Oxf) 200461 431-436.

Received 21 July 2006

Accepted 2 October 2006 